\title{
Remarkable Anticancer Activity of Triruthenium-Arene Clusters Compared to Tetraruthenium-Arene Clusters*
}

\author{
Bruno Therrien, ${ }^{1}$ Wee Han Ang, ${ }^{2}$ Frédéric Chérioux, ${ }^{1,3}$ \\ Ludovic Vieille-Petit, ${ }^{1}$ Lucienne Juillerat-Jeanneret, ${ }^{4}$ \\ Georg Süss-Fink, ${ }^{1,5}$ and Paul J. Dyson ${ }^{2,5}$
}

Received May 3, 2007; accepted May 29, 2007

\begin{abstract}
The in vitro activity of a series of ruthenium clusters, $\left[\left(\eta^{6}-\mathrm{C}_{6} \mathrm{H}_{6}\right)\left(\eta^{6}-\mathrm{C}_{6} \mathrm{Me}_{6}\right)_{2}\right.$ $\left.\mathrm{Ru}_{3}(\mu-\mathrm{H})_{3}\left(\mu_{3}-\mathrm{O}\right)\right]\left[\mathrm{BF}_{4}\right],\left[\left(\eta^{6}-\mathrm{C}_{6} \mathrm{H}_{6}\right)\left(\eta^{6}-1,4-{ }^{\mathrm{i}} \mathrm{PrC}_{6} \mathrm{H}_{4} \mathrm{Me}\right)\left(\eta^{6}-\mathrm{C}_{6} \mathrm{Me}_{6}\right) \mathrm{Ru}_{3}(\mu-\mathrm{H})_{3}\left(\mu_{3}-\right.\right.$ $\mathrm{O})]\left[\mathrm{BF}_{4}\right], \quad\left[\left(\eta^{6}-\mathrm{C}_{6} \mathrm{H}_{6}\right)_{4} \mathrm{Ru}_{4}(\mu-\mathrm{H})_{4}\right]\left[\mathrm{BF}_{4}\right]_{2}, \quad\left[\left(\eta^{6}-\mathrm{C}_{6} \mathrm{H}_{5} \mathrm{Me}\right)_{4} \mathrm{Ru}_{4}(\mu-\mathrm{H})_{4}\right]\left[\mathrm{BF}_{4}\right]_{2}$ and $\left[\left(\eta^{6}-\mathrm{C}_{6} \mathrm{H}_{6}\right)_{4} \mathrm{Ru}_{4}(\mu-\mathrm{H})_{3}(\mu-\mathrm{OH})\right][\mathrm{Cl}]_{2}$, has been evaluated against $\mathrm{A} 2780$ and A2780cisR ovarian carcinoma cell lines. Both triruthenium clusters are very active compared to ruthenium compounds in general, whereas the tetraruthenium clusters do not display significant cytotoxicities. Since the triruthenium clusters are known to form supramolecular interactions with arenes and other functions, it is possible that such interactions are also important with respect to their mode of biological activity. The X-ray structure analysis of $\left[\left(\eta^{6}-\mathrm{C}_{6} \mathrm{H}_{5} \mathrm{Me}\right)_{4} \mathrm{Ru} u_{4}\right.$ $\left.(\mu-\mathrm{H})_{4}\right]\left[\mathrm{PF}_{6}\right]_{2}$ is also reported.
\end{abstract}

KEY WORDS: Clusters; bioorganometallic chemistry; medicinal chemistry; bioinorganic chemistry; ruthenium; in vitro assays; anticancer drugs.

\section{INTRODUCTION}

Recent years have witnessed a tremendous increase in research into anticancer compounds based on ruthenium with two ruthenium coordina-

*Dedicated to Professor Dieter Fenske on the occasion of his 65th birthday anniversary

${ }^{1}$ Institut de Chimie, Université de Neuchâtel, Case postale 158, 2009, Neuchâtel, Switzerland.

${ }^{2}$ Institut des Sciences et Ingénierie Chimiques, Ecole Polytechnique Fédérale de Lausanne (EPFL), 1015, Lausanne, Switzerland.

${ }^{3}$ Laboratoire FEMTO-ST, UMR CNRS 6174, 32 Avenue de l'Observatoire, 25044, Besançon cedex, France.

${ }^{4}$ Centre Hospitalier Universitaire Vaudois (CHUV), University Institute of Pathology, 1011, Lausanne, Switzerland.

${ }^{5}$ To whom correspondence should be addressed. E-mail: georg.suess-fink@unine.ch; paul. dyson@epfl.ch 
tion compounds (Fig. 1) that have a different spectrum of activity to platinum drugs [1] currently undergoing clinical evaluation [2]. Notably, the differing activity is assigned to a different mode of action guided by the high affinity of ruthenium(III) compounds toward proteins [3].

More recently, interest has focused on organometallic compounds [4], specifically on ruthenium(II)-arene compounds, which show excellent antiproliferative properties both in vitro and in vivo [5]. It has been found that a structurally diverse range of compounds all exhibit interesting properties. For example, a wide range of arenes can be tolerated and the arene can even be replaced by cyclopentadienyl, pentamethylcyclopentadienyl [6] or the sulphur macrocycle 1,4,7-trithiacyclononane without affecting the in vitro activity significantly [7]. It has even been found that some rhodium and osmium analogues, evaluated in HT29 colon carcinoma, A549 lung carcinoma and T47D breast carcinoma cell lines in vitro, display activities that are not too dissimilar from the related ruthenium(II)-arene complexes [8]. A feature of many of these compounds, notably those with the 1,3,5-triaza-7-phosphatricyclo[3.3.1.1]decane (pta) ligand, is that although the activity is lower than that of cisplatin and related $\mathrm{Pt}(\mathrm{II})$ compounds in vitro, the activity against metastatic (secondary) tumours evaluated in vivo is high in the absence of activity against the primary cancers [9]. Furthermore, more cytotoxic agents can be prepared by incorporating specific ligands of known biological function [10].

Metal clusters based on ruthenium, osmium and rhodium have been shown to exhibit medicinal properties. In particular, it has been postulated that the pharmacological properties of cluster complexes, including $\mathrm{Ru}_{3}(\mathrm{CO})_{9}(\mathrm{pta})_{3},\left[\mathrm{Pt}_{3}\left(\mu_{3}-\mathrm{CO}\right)(\mu-\mathrm{dppm})_{3}\right]^{2+}, \mathrm{HO}_{3}(\mathrm{CO})_{9}(\mu-\mathrm{L}-\mathrm{H}) \mathrm{L}^{\prime}$ $\left[\mathrm{L}=3\right.$-amino quinoline, $\mathrm{L}^{\prime}=\mathrm{P}\left(\mathrm{C}_{6} \mathrm{H}_{4} \mathrm{SO}_{3} \mathrm{Na}\right)_{3}$ or $\mathrm{P}\left(\mathrm{OCH}_{2} \mathrm{CH}_{2} \mathrm{NMe}_{3} \mathrm{I}\right)_{3}$;

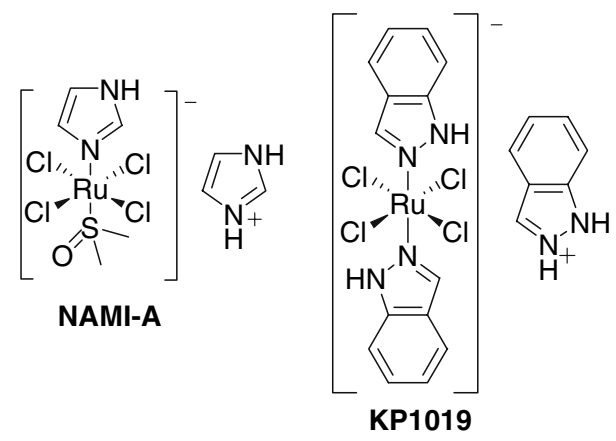

Fig. 1 Clinically evaluated ruthenium-based anticancer drugs 
$\mathrm{L}=3$-(2-phenylacetimido)-quinoline, $\mathrm{L}^{\prime}=\mathrm{P}\left(\mathrm{OCH}_{2} \mathrm{CH}_{2} \mathrm{NMe}_{3} \mathrm{I}\right)_{3}$ or $\mathrm{L}=$ phenanthridine, $\left.\quad \mathrm{L}^{\prime}=\mathrm{P}\left(\mathrm{OCH}_{2} \mathrm{CH}_{2} \mathrm{NMe}_{3} \mathrm{I}\right)_{3}\right]$ and $\mathrm{Rh}_{3}\left(\mu_{3}-\mathrm{S}\right)_{2}\left(\eta^{5}-\mathrm{C}_{5}\right.$ $\left.\left(\mathrm{Me}_{5}\right)_{3}\right]^{2+}$, are related to their ability to damage DNA, [11] although enzyme inhibition could also be important [12]. While ruthenium-arene complexes in which two ruthenium centres are bridged by a ligand have received some attention, ruthenium-arene clusters with direct metal-metal bonds have not been fully explored as potential anticancer agents.

Interest in clusters as anticancer agents also originated from the notion that they could be rationally developed to target tumours specifically, exploiting the 'enhanced permeability and retention' (EPR) effect. The EPR effect is a phenomenon in which macromolecules are able to accumulate at the tumour site due to the dramatic increase in blood vessel permeability within diseased tissues compared to normal tissues [13]. The normal endothelial layer surrounding the blood vessels feeding healthy tissues is intact, restricting the size of molecules that can diffuse from the blood. In contrast, the endothelial layer of blood vessels in diseased tissues is more porous to large molecules providing access to the surrounding tissue. Furthermore, diseased tissue does not generally have a lymphatic drainage system; hence once macromolecules have entered the tissue they are retained. Notably, the cluster $\left[\left(\eta^{6}-\mathrm{C}_{6} \mathrm{H}_{6}\right) \mathrm{Ru}_{4}\left(\mu_{3}-\mathrm{H}\right)_{4}\right]^{2+}$ was even found to be highly active against the polio virus without damaging the host cells, thereby offering the potential of developing it into a highly selective drug [14].

Based on such nascent encouraging results we decided to evaluate a series of triruthenium- and tetraruthenium-arene clusters for in vitro activity evaluated against A2780 and A2780cisR ovarian carcinoma cell lines, the latter being ca. 6-fold resistant to cisplatin treatment. The outcome of these experiments is described herein.

\section{RESULTS AND DISCUSSION}

A series of ruthenium clusters with nuclearities of three and four, specifically, $\left[\left(\eta^{6}-\mathrm{C}_{6} \mathrm{H}_{6}\right)\left(\eta^{6}-\mathrm{C}_{6} \mathrm{Me}_{6}\right)_{2} \mathrm{Ru}_{3}(\mu-\mathrm{H})_{3}\left(\mu_{3}-\mathrm{O}\right)\right]\left[\mathrm{BF}_{4}\right] \quad \mathbf{1 a}, \quad[15]\left[\left(\eta^{6}-\right.\right.$ $\left.\left.\mathrm{C}_{6} \mathrm{H}_{6}\right)\left(\eta^{6}-1,4-{ }^{i} \mathrm{PrC}_{6} \mathrm{H}_{4} \mathrm{Me}\right)\left(\eta^{6}-\mathrm{C}_{6} \mathrm{Me}_{6}\right) \mathrm{Ru}_{3}(\mu-\mathrm{H})_{3}\left(\mu_{3}-\mathrm{O}\right)\right]\left[\mathrm{BF}_{4}\right] \quad \mathbf{1 b}$, [16] [( $\eta^{6}-$ $\left.\left.\mathrm{C}_{6} \mathrm{H}_{6}\right)_{4} \mathrm{Ru}_{4}(\mu-\mathrm{H})_{4}\right]\left[\mathrm{BF}_{4}\right]_{2}$ 2a [17], $\left[\left(\eta^{6}-\mathrm{C}_{6} \mathrm{H}_{5} \mathrm{Me}\right)_{4} \mathrm{Ru}_{4}(\mu-\mathrm{H})_{4}\right]\left[\mathrm{BF}_{4}\right]_{2}$ 2b and $\left[\left(\eta^{6}-\mathrm{C}_{6} \mathrm{H}_{6}\right)_{4} \mathrm{Ru}_{4}(\mu-\mathrm{H})_{3}(\mu-\mathrm{OH})\right][\mathrm{Cl}]_{2} \mathbf{2 c}[18]$ (see Chart 1) were prepared using literature methods. Compound $\mathbf{2} \mathbf{b}$ is new and was isolated from the reaction of $\left[\left(\eta^{6}-\mathrm{C}_{6} \mathrm{H}_{5} \mathrm{Me}\right) \mathrm{Ru}(\mu-\mathrm{Cl}) \mathrm{Cl}\right]_{2}$ in water with molecular hydrogen $(55 \mathrm{~atm}$, $\left.60{ }^{\circ} \mathrm{C}\right)$ which gives the tetranuclear hexahydrido cluster $\left[\left(\eta^{6}-\mathrm{C}_{6} \mathrm{H}_{5} \mathrm{Me}\right)_{4}\right.$ $\left.\mathrm{Ru}_{4}(\mu-\mathrm{H})_{6}\right]^{2+}$ that further reacts slowly with oxygen to form the tetrahydrido cluster isolated as the tetrafluoroborate salt $\mathbf{2 b}$. 


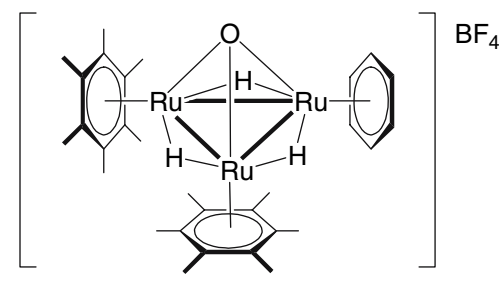

1a

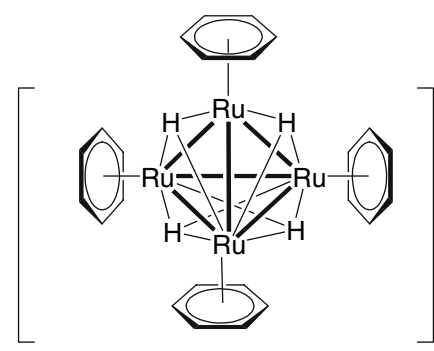

$2 a$

$2 \mathrm{BF}_{4}$

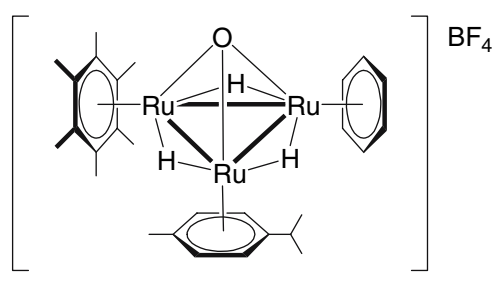

1b

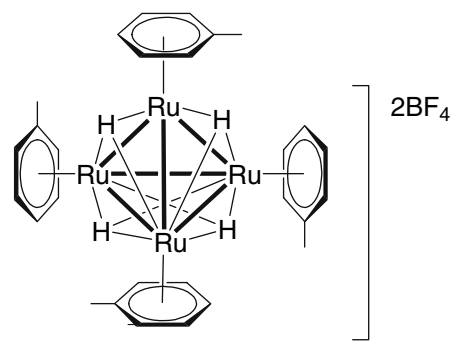

$\mathbf{2 b}$
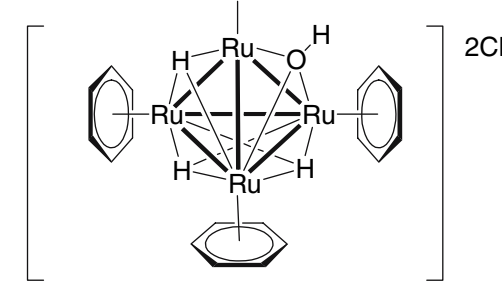

2c

Chart 1 Trinuclear $(\mathbf{1 a}, \mathbf{1 b})$ and tetranuclear (2a-2c) ruthenium clusters evaluated for anticancer activity in vitro

The ${ }^{1} \mathrm{H}$ NMR spectrum of $\mathbf{2} \mathbf{b}$ in $\mathrm{D}_{2} \mathrm{O}$ gives, other than the aromatic protons of the toluene ligands in the region $5.5-6.0 \mathrm{ppm}$ and the corresponding methyl signal at $\delta=2.1 \mathrm{ppm}$, a singlet hydride signal at $-17.7 \mathrm{ppm}$. The mass spectrum of $\left[\left(\eta^{6}-\mathrm{C}_{6} \mathrm{H}_{5} \mathrm{Me}\right)_{4} \mathrm{Ru}_{4}(\mu-\mathrm{H})_{4}\right]\left[\mathrm{BF}_{4}\right]_{2}$ exhibits the $[\mathrm{M}+\mathrm{H}]^{+}$pseudomolecular ion peak $m / z$ at 777.9 .

The chloro or tetrafluoroborate salts of $\left[\left(\eta^{6}-\mathrm{C}_{6} \mathrm{H}_{5} \mathrm{Me}\right)_{4} \mathrm{Ru}_{4}\left(\mu_{3}-\mathrm{H}\right)_{4}\right]^{2+}$ did not yield single crystals that are of sufficient quality for X-ray diffraction analyses. However, single crystals of the black hexafluorophosphate salt $\left[\left(\eta^{6}-\mathrm{C}_{6} \mathrm{H}_{5} \mathrm{Me}\right)_{4} \mathrm{Ru}_{4}\left(\mu_{3}-\mathrm{H}\right)_{4}\right]\left[\mathrm{PF}_{6}\right]_{2}$ were obtained via slow evaporation from 
Table 1 Selected bond lengths $(\AA)$ and angles $\left(^{\circ}\right)$ for $\left[\left(\eta^{6}-\mathrm{C}_{6} \mathrm{H}_{5} \mathrm{Me}\right)_{4} \mathrm{Ru}_{4}\left(\mu_{3}-\mathrm{H}\right)_{4}\right]\left[\mathrm{PF}_{6}\right]_{2}$ (cation of $\mathbf{2 b}$ ) and $\left[\left(\eta^{6}-\mathrm{C}_{6} \mathrm{H}_{6}\right)_{4} \mathrm{Ru}_{4}\left(\mu_{3}-\mathrm{H}\right)_{4}\right][\mathrm{Cl}]_{2}(\text { cation of } \mathbf{2 a})^{[17]}$

\begin{tabular}{lll} 
& {$\left[\left(\eta^{6}-\mathrm{C}_{6} \mathrm{H}_{5} \mathrm{Me}\right)_{4} \mathrm{Ru}_{4}\left(\mu_{3}-\mathrm{H}\right)_{4}\right]\left[\mathrm{PF}_{6}\right]_{2}$} & {$\left[\left(\eta^{6}-\mathrm{C}_{6} \mathrm{H}_{6}\right)_{4} \mathrm{Ru}_{4}\left(\mu_{3}-\mathrm{H}\right)_{4}\right][\mathrm{Cl}]_{2}$} \\
\hline $\mathrm{Ru}-\mathrm{Ru}$ (range) & $2.667(1)-2.770(1)$ & $2.729(2)-2.730(2)$ \\
$\mathrm{Ru}-\mathrm{Ru}$ (mean) & 2.724 & 2.730 \\
$\mathrm{Ru}-\mathrm{C}$ (range) & $2.18(1)-2.28(1)$ & $2.15(1)-2.23(1)$ \\
$\mathrm{Ru}-\mathrm{C}$ (mean) & 2.21 & 2.18 \\
$\mathrm{Ru}-\mathrm{Ru}-\mathrm{Ru}$ (range) & $57.86(3)-61.61(3)$ & $59.96(2)-60.03(2)$ \\
$\mathrm{Ru}-\mathrm{Ru}-\mathrm{Ru}$ (mean) & 59.23 & 60.02 \\
$\mathrm{Ru}-\mathrm{H}$ (mean) & 1.79 & 2.02 \\
$\mathrm{Ru}-\mathrm{H}-\mathrm{Ru}$ (mean) & 100.4 & 81.4 \\
$\mathrm{C}-\mathrm{C}_{\mathrm{Me}}$ (range) & $1.42(2)-1.52(2)$ & \\
\hline
\end{tabular}

a concentrated methanol solution. The ORTEP representation of the dication $\left[\left(\eta^{6}-\mathrm{C}_{6} \mathrm{H}_{5} \mathrm{Me}\right)_{4} \mathrm{Ru}_{4}\left(\mu_{3}-\mathrm{H}\right)_{4}\right]^{2+}$ is shown in Fig. 2. Selected bond lengths and angles are presented in Table 1 and compared to the geometrical parameters of the analogous tetranuclear benzene derivative $\left[\left(\eta^{6}-\right.\right.$ $\left.\left.\mathrm{C}_{6} \mathrm{H}_{6}\right)_{4} \mathrm{Ru}_{4}\left(\mu_{3}-\mathrm{H}\right)_{4}\right][\mathrm{Cl}]_{2}[17]$.

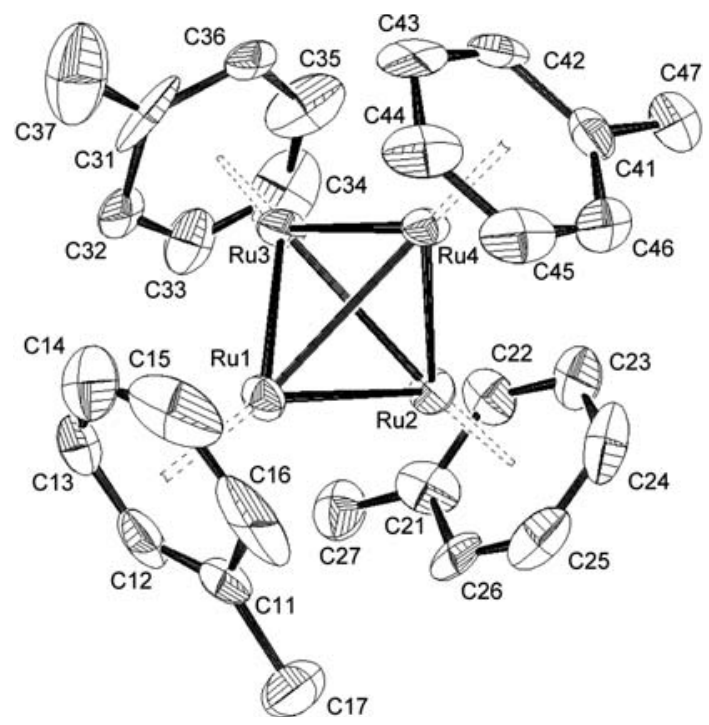

Fig. 2 ORTEP view of $\left[\left(\eta^{6}-\mathrm{C}_{6} \mathrm{H}_{5} \mathrm{Me}\right)_{4} \mathrm{Ru}_{4}\left(\mu_{3}-\mathrm{H}\right)_{4}\right]^{2+}$ (cation of $2 \mathbf{b}$ ) with displacement ellipsoids drawn at the $50 \%$ probability level; H-atoms and hexafluorophosphate anions being omitted for clarity 
The single-crystal X-ray structure analysis of $\left[\left(\eta^{6}-\mathrm{C}_{6} \mathrm{H}_{5} \mathrm{Me}\right)_{4} \mathrm{Ru}_{4}\left(\mu_{3^{-}}\right.\right.$ $\left.\mathrm{H})_{4}\right]\left[\mathrm{PF}_{6}\right]_{2}$ indicates that the dication $\left[\left(\eta^{6}-\mathrm{C}_{6} \mathrm{H}_{5} \mathrm{Me}\right)_{4} \mathrm{Ru}_{4}\left(\mu_{3}-\mathrm{H}\right)_{4}\right]^{2+}$ consist of a tetranuclear ruthenium framework which co-ordinates four toluene ligands. The four metal atoms form a slightly distorted tetrahedron with $\mathrm{Ru}-\mathrm{Ru}-\mathrm{Ru}$ angles ranging from 57.86(3) to $61.61(3)^{\circ}$. The toluene ligands are $\eta^{6}$-bound to the ruthenium atom with an average $\mathrm{Ru}-\mathrm{C}$ distance of $2.21 \AA$, differing only slightly from that observed in $\left[\left(\eta^{6}-\mathrm{C}_{6} \mathrm{H}_{6}\right)_{4} \mathrm{Ru}_{4}\left(\mu_{3}\right.\right.$ $\left.\mathrm{H})_{4}\right][\mathrm{Cl}]_{2}[2.18(1) \AA][17]$. The carbon atoms of the methyl groups are displaced by less than $0.10(2) \AA$ from the plane of the aromatic rings. Unfortunately, the hydrido ligands could not be located from Fourier difference map, and therefore fixed as symmetrical $\mu_{3}$-capped ligands above the $\mathrm{Ru}_{3}$ triangles, as with other reported examples. In the crystal packing of $\left[\left(\eta^{6}-\mathrm{C}_{6} \mathrm{H}_{5} \mathrm{Me}\right)_{4} \mathrm{Ru}_{4}\left(\mu_{3}-\mathrm{H}\right)_{4}\right]\left[\mathrm{PF}_{6}\right]_{2}$, the hexafluorophosphate anions are intercalated between the cationic clusters and interact weakly with $\left[\left(\eta^{6}-\right.\right.$ $\left.\left.\mathrm{C}_{6} \mathrm{H}_{5} \mathrm{Me}\right)_{4} \mathrm{Ru}_{4}\left(\mu_{3}-\mathrm{H}\right)_{4}\right]^{2+}$ through multiple $\mathrm{C}-\mathrm{H} \cdots \mathrm{F}$ contacts; the $\mathrm{C} \cdots \mathrm{F}$ distances ranging from 3.16 to $3.56 \AA$ and the $\mathrm{C}-\mathrm{H} \cdots \mathrm{F}$ angles from 119.4 to $169.6^{\circ}$.

The ability of the compounds to inhibit cancer cell viability was performed against two different ovarian cancer cell lines, A2780 and its cisplatin-resistant strain A2780cisR, which exhibit a 6-fold increase in cisplatin resistance. The effects of the clusters on the cancer cell growth were evaluated after an exposure period of $72 \mathrm{~h}$ using the MTT [3-(4,5dimethylthiazol-2-yl)-2,5-diphenyltetrazolium bromide] assay, which measures mitochondrial dehydrogenase activity as an indication of cell viability. The $\mathrm{IC}_{50}$ values for the inhibition of cell viability of the complexes are listed in Table 2. In addition, the dose-response curves for $\mathbf{1 a}$ and $\mathbf{1 b}$ against the two cell lines are illustrated in Fig. 3.

From Table 2 it is clear that, while both the triruthenium clusters (1a and $\mathbf{1 b}$ ) are remarkably active in both cell lines, both being slightly less active in the cisplatin-resistant A2780cisR cell line, the tetraruthenium

Table 2 Inhibition of cell viability $\left(\mathrm{IC}_{50}\right)$ of complexes on A2780 and A2780cisR ovarian carcinoma cell lines after $72 \mathrm{~h}$ of incubation, determined using MTT assay

\begin{tabular}{lcc}
\hline Compounds & A2780 & A2780cisR \\
\hline Cisplatin & $1.5 \pm 0.3$ & $8.7 \pm 1.6$ \\
RAPTA-C & $>100$ & $>100$ \\
$\mathbf{~ a}$ & $9.8 \pm 0.2$ & $14.6 \pm 0.7$ \\
$\mathbf{1 b}$ & $9.1 \pm 0.9$ & $28.9 \pm 2.8$ \\
$\mathbf{2 a}$ & $>100$ & $>100$ \\
$\mathbf{2 b}$ & $>100$ & $>100$ \\
$\mathbf{2 c}$ & $>100$ & $>100$ \\
\hline
\end{tabular}



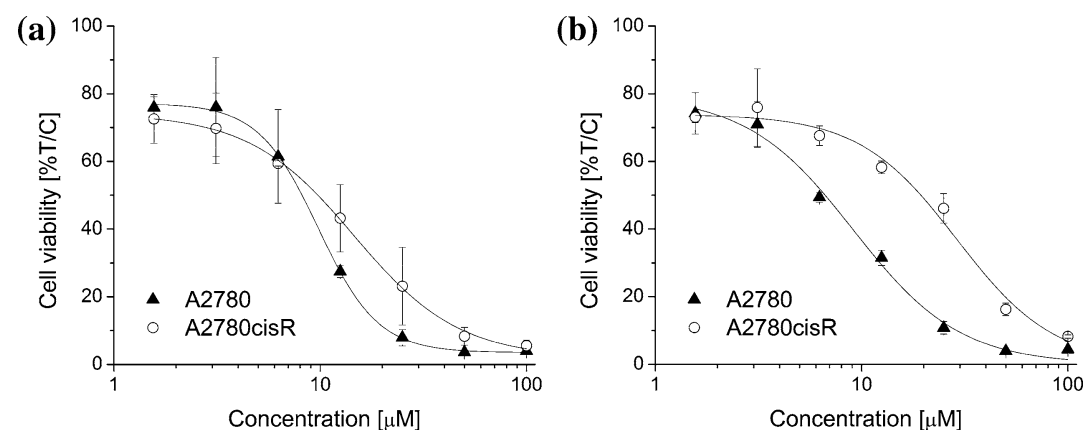

Fig. 3 Dose-response curves of exposure of compounds 1a (left) and 1b (right) to A2780 and A2780cisR ovarian carcinoma cell lines, determined using MTT assay

clusters (2a-2c) are not cytotoxic. Although the values are about 3-6 times higher than cisplatin, they are low in comparison to ruthenium-based complexes, typically 20-30 times lower than the class of antimetastatic ruthenium(II)-arene complexes containing the pta ligand (RAPTA-C). The activities are also significantly higher than organometallic ruthenium complexes containing imidazolium, [19] dihydroxypyridyl, ferrocenyl and polyoxomolybdenum clusters [20] screened for inhibition of cancer cell growth ability against the same cell lines under similar condition. To date, they are some of the most active ruthenium-cluster anticancer compounds reported.

It is interesting to consider why the triruthenium clusters are highly cytotoxic in comparison to the tetraruthenium clusters. The two classes of clusters exhibit one major difference with respect to their chemical reactivity; the triruthenium clusters present a hydrophobic pocket and a $\mu_{3}$-oxo ligand, which could form supramolecular interactions with arenes and other functions, see Fig. 4. Indeed, the hydrophobic pocket spanned by the three arene ligands can accommodate arene moieties [21], while the $\mu_{3}$-oxo ligand interacts strongly with hydroxyl groups [22]. By contrast, the tetraruthenium clusters do not contain a hydrophobic pocket or a $\mu_{3}$-oxo ligand, and it is therefore tempting to attribute the cytotoxic activity of $\mathbf{1 a}$ and $\mathbf{1 b}$ to a supramolecular recognition process within the cancer cell. Since hydrophobic arene units and hydroxyl groups are usually buried inside proteins, it is possible that a highly selective process is in operation. Clearly, further experiments are required to prove such a hypothesis, but nevertheless, the correlation between the known supramolecular interactions of $\mathbf{1 a}$ and $\mathbf{1 b}$ and their excellent activity in the ovarian cell lines is striking. 


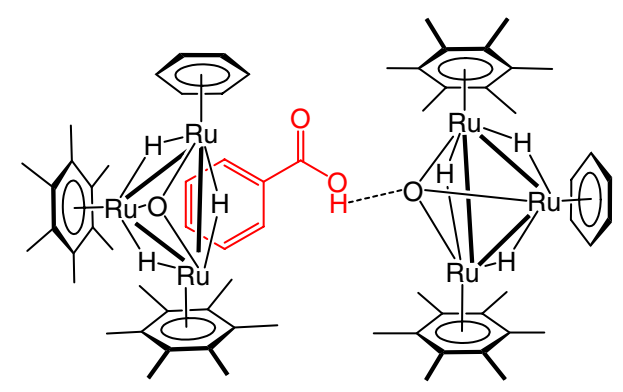

Fig. 4 Typical supramolecular interactions observed in $\mathbf{1}$ [23]

\section{EXPERIMENTAL}

The compounds $\mathbf{1 a}, \mathbf{1 b}, \mathbf{2 a}, \mathbf{2} \mathbf{c}$ were prepared according to literature procedures [15-18]. The precursor $\left[\left(\eta^{6}-\mathrm{C}_{6} \mathrm{H}_{5} \mathrm{Me}\right) \mathrm{Ru}(\mu-\mathrm{Cl}) \mathrm{Cl}\right]_{2}$ was prepared according to the published method [23]. The ${ }^{1} \mathrm{H}$ NMR spectrum was recorded using a Varian Gemini $200 \mathrm{MHz}$ spectrometer. Microanalysis was performed by the Laboratory of Pharmaceutical Chemistry, University of Geneva (Switzerland). Electro-spray mass spectrum was obtained in positive-ion mode with an LCQ Finnigan mass spectrometer.

\section{Synthesis of $\left[\left(\eta^{6}-\mathrm{C}_{6} \mathrm{H}_{5} \mathrm{Me}\right)_{4} \mathrm{Ru}_{4}\left(\mu_{3}-\mathrm{H}\right)_{4}\right]\left[\mathrm{BF} \mathbf{F}_{2}(2 \mathrm{~b})\right.$}

A suspension of $\left[\left(\eta^{6}-\mathrm{C}_{6} \mathrm{H}_{5} \mathrm{Me}\right) \mathrm{Ru}(\mu-\mathrm{Cl}) \mathrm{Cl}\right]_{2}(158 \mathrm{mg}, 0.3 \mathrm{mmol})$ in $\mathrm{H}_{2} \mathrm{O}(20 \mathrm{ml})$ was hydrogenated in a stainless-steel autoclave at $60{ }^{\circ} \mathrm{C}$ under a pressure of 55 bar. After $24 \mathrm{~h}$ the autoclave was cooled, the pressure released and the violet solution filtered on celite. The water was removed under reduced pressure and the violet residue dissolved in methanol $(15 \mathrm{~mL})$ and stirred under air for 2 days. Evaporation of most of the solvent, followed by precipitation at $-10^{\circ} \mathrm{C}$, gave the dichloride salt $\left[\left(\eta^{6}\right.\right.$ $\left.\left.\mathrm{C}_{6} \mathrm{H}_{5} \mathrm{Me}\right)_{4} \mathrm{Ru}_{4}\left(\mu_{3}-\mathrm{H}\right)_{4}\right][\mathrm{Cl}]_{2}$ as a dark violet solid. Anion exchange is performed in methanol with an excess of $\mathrm{NaBF}_{4}$ and precipitation at $-10{ }^{\circ} \mathrm{C}$ to afford the tetrafluoroborate salt $\left[\left(\eta^{6}-\mathrm{C}_{6} \mathrm{H}_{5} \mathrm{Me}\right)_{4} \mathrm{Ru}_{4}\left(\mu_{3}-\mathrm{H}\right)_{4}\right]\left[\mathrm{BF}_{4}\right]_{2}$ $(80 \mathrm{mg}, 56 \%) .{ }^{1} \mathrm{H}$ NMR $\left(200 \mathrm{MHz}, \mathrm{D}_{2} \mathrm{O}\right): \delta(\mathrm{ppm})=6.01(\mathrm{~m}, 3 \mathrm{H}) 5.57(\mathrm{~m}$, $2 \mathrm{H}) 2.12(\mathrm{~s}, 3 \mathrm{H})-17.71(\mathrm{~s}, 1 \mathrm{H})$. ESI-MS: $m / z 777.90[\mathrm{M}+\mathrm{H}]^{+}$. Elemental analysis (\%) calc. for $\mathrm{C}_{28} \mathrm{H}_{36} \mathrm{~B}_{2} \mathrm{~F}_{8} \mathrm{Ru}_{4}$ : $\mathrm{C}, 35.38 ; \mathrm{H}, 3.82$ Found: $\mathrm{C}, 35.65 ; \mathrm{H}$, 4.01 . 


\section{Solid-State Structural Determination of $\left[\left(\eta^{6}-\mathrm{C}_{6} \mathrm{H}_{5} \mathrm{Me}\right)_{4} \mathrm{Ru}_{4}\left(\mu_{3}-\mathrm{H}_{4}\right)_{4}\left[\mathrm{PF}_{6} \mathrm{l}_{2}\right.\right.$ (cation of 2b)}

Single crystals of $\left[\left(\eta^{6}-\mathrm{C}_{6} \mathrm{H}_{5} \mathrm{Me}\right)_{4} \mathrm{Ru}_{4}\left(\mu_{3}-\mathrm{H}\right)_{4}\right]\left[\mathrm{PF}_{6}\right]_{2}$ suitable for X-ray diffraction analysis were obtained after addition of a small amount of $\mathrm{KPF}_{6}$ to a methanol solution containing $\left[\left(\eta^{6}-\mathrm{C}_{6} \mathrm{H}_{5} \mathrm{Me}\right)_{4} \mathrm{Ru}_{4}\left(\mu_{3}-\mathrm{H}\right)_{4}\right][\mathrm{Cl}]_{2}$. A crystal of $\left[\left(\eta^{6}-\mathrm{C}_{6} \mathrm{H}_{5} \mathrm{Me}\right)_{4} \mathrm{Ru}_{4}\left(\mu_{3}-\mathrm{H}\right)_{4}\right]\left[\mathrm{PF}_{6}\right]_{2}$ was mounted on a Stoe Image Plate Diffraction System equipped with a $\varphi$ circle goniometer, using Mo-K $\alpha$ graphite monochromated radiation $(\lambda=0.71073 \AA)$ with $\varphi$ range $0-200^{\circ}$, increment of $1.2^{\circ}, D_{\max }-D_{\min }=12.45-0.81 \AA$. The structure was solved by direct methods using the program SHELXS-97 [24]. The refinement and all further calculations were carried out using SHELXL-97 [25]. The hydrogen atoms have been included in calculated positions and treated as riding atoms using the SHELXL default parameters. All non-H atoms were refined anisotropically, using weighted full-matrix least-square on $F^{2}$. All residual

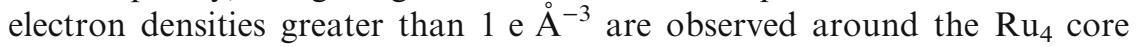
and $\mathrm{PF}_{6}$ anions. The final flack parameter was $0.49(8)$, thus suggesting a racemically twinned crystal, however twin refinement did not improve the resolution. Graphical representations were made using ORTEP-32 [26]. Crystallographic details are summarised in Table 3.

CCDC 640690 contains the supplementary crystallographic data for this paper. These data can be obtained free of charge from The Cambridge Crystallographic Data Centre via www.ccdc.cam.ac.uk/data_request/cif.

\section{Cell Culture}

Human A2780 and A2780cisR ovarian carcinoma cell lines were obtained from the European Centre of Cell Cultures (ECACC, Porton down, Salisbury, UK). All other cell culture reagents were obtained from Gibco-BRL, Basel, Switzerland. The cells were routinely grown in RPMI 1640 medium containing $10 \%$ foetal calf serum (FCS) and antibiotics at $37{ }^{\circ} \mathrm{C}$ and $6 \% \mathrm{CO}_{2}$. For the MTT tests, the cells were seeded in 96-well plates (Costar, Integra Biosciences, Cambridge, MA, USA) as monolayers for $24 \mathrm{~h}$ in complete medium with $10 \% \mathrm{FCS}$, then fresh complete medium with 5\% FCS was added together with the drugs, and culture was continued for another $72 \mathrm{~h}$. The test (see below) was performed for the last $2 \mathrm{~h}$ without changing the culture medium.

\section{Determination of Cell Viability}

The compounds were dissolved directly in culture medium to the required concentration. Cell viability was determined using the MTT assay which allows the quantification of the mitochondrial activity in 
Table 3 Crystallographic data of $\left[\left(\eta^{6}-\mathrm{C}_{6} \mathrm{H}_{5} \mathrm{Me}\right)_{4} \mathrm{Ru}_{4}\left(\mu_{3}-\mathrm{H}\right)_{4}\right]\left[\mathrm{PF}_{6}\right]_{2}$

\begin{tabular}{ll}
\hline & {$\left[\left(\eta^{6}-\mathrm{C}_{6} \mathrm{H}_{5} \mathrm{Me}_{4} \mathrm{Ru}_{4}\left(\mu_{3}-\mathrm{H}\right)_{4}\right]\left[\mathrm{PF}_{6}\right]_{2}\right.$} \\
\hline Chemical formula & $\mathrm{C}_{28} \mathrm{H}_{36} \mathrm{~F}_{12} \mathrm{P}_{2} \mathrm{Ru}_{4}$ \\
Formula weight & 1066.79 \\
Crystal system & Orthorhombic \\
Space group & $P 2_{1} 2_{1} 2_{1}$ \\
Crystal colour and shape & Black plate \\
Crystal size & $0.40 \times 0.24 \times 0.08$ \\
$a(\AA)$ & $10.197(2)$ \\
$b(\AA)$ & $16.825(3)$ \\
$c(\AA)$ & $19.101(4)$ \\
$V\left(\AA^{3}\right)$ & $3277.1(11)$ \\
$Z$ & 4 \\
$T(\mathrm{~K})$ & $173(2)$ \\
$D_{\mathrm{c}}\left(\mathrm{g} \cdot \mathrm{cm}{ }^{-3}\right)$ & 2.162 \\
$\mu\left(\mathrm{mm}{ }^{-1}\right)$ & 1.995 \\
Scan range $\left({ }^{\circ}\right)$ & $4.52<2 \theta<51.98$ \\
Unique reflections & 6084 \\
Reflections used $[\mathrm{I}>2 \sigma(\mathrm{I})]$ & 5618 \\
$R_{\text {int }}$ & 0.0492 \\
Flack parameter & $0.49(8)$ \\
Final $R$ indices $[\mathrm{I}>2 \sigma(\mathrm{I})]^{a}$ & $0.0523, w R_{2} 0.1365$ \\
$R$ indices (all data) & $0.0570, w R_{2} 0.1391$ \\
Goodness-of-fit & 1.054 \\
Max, Min $\Delta \rho / \mathrm{e}\left(\AA^{-3}\right)$ & $2.984,-2.738$ \\
\hline
\end{tabular}

${ }^{a}$ Structure was refined on $\mathrm{F}_{0}{ }^{2}: \mathrm{wR}_{2}=\left[\mathrm{T}\left[\mathrm{w}\left(\mathrm{F}_{0}{ }^{2}-\mathrm{F}_{\mathrm{c}}{ }^{2}\right)^{2}\right] / \mathrm{Tw}\left(\mathrm{F}_{0}{ }^{2}\right)^{2}\right]^{1 / 2}$, where $\mathrm{w}^{-1}=\left[\mathrm{T}\left(\mathrm{F}_{0}^{2}\right)+(\mathrm{aP})^{2}+\mathrm{bP}\right]$ and $\mathrm{P}=\left[\max \left(\mathrm{F}_{0}^{2}, 0\right)+2 \mathrm{~F}_{\mathrm{c}}^{2}\right] / 3$

metabolically active cells. Following drug exposure, MTT (final concentration $0.2 \mathrm{mg} / \mathrm{mL}$ ) was added to the cells for $2 \mathrm{~h}$, then the culture medium was aspirated and the violet formazan precipitate dissolved in $0.1 \mathrm{~N} \mathrm{HCl}$ in 2-propanol. The optical density, which is directly proportional to number of surviving cells, was quantified at $540 \mathrm{~nm}$ using a multiwell plate reader (iEMS Reader MF, Labsystems, US) and the percentage of surviving cells was calculated from the absorbance of untreated control cells. The $\mathrm{IC}_{50}$ values for the inhibition of cell viability were determined by fitting the plot of the percentage of surviving cells against the drug concentration using a sigmoidal function (OriginPro).

\section{ACKNOWLEDGEMENT}

The authors are grateful to the Fonds National Suisse de la Recherche Scientifique for financial support. A generous loan of ruthenium 
chloride hydrate from the Johnson Matthey Technology Centre is gratefully acknowledged.

\section{REFERENCES}

1. E. Alessio, G. Mestroni, A. Bergamo, and G. Sava (2004). Met. Ions Biol. Syst. 42, 323.

2. (a) C. G. Hartinger, S. Zorbas-Selfried, M. A. Jakupec, B. Kynast, H. Zorbas and B. K. Keppler (2006), J. Inorg. Biochem. 100, 891. (b) E. Alessio, G. Mestroni, A. Bergamo and G. Sava (2004), Curr. Top. Med. Chem. 4, 1525.

3. (a) A. R. Timerbaev, C. G. Hartinger, S. S. Aleksenko and B. K. Keppler (2006), Chem. Rev. 106, 2224. (b) P. J. Dyson and G. Sava (2006) Dalton Trans., 1929.

4. (a) C. S. Allardyce, A. Dorcier, C. Scolaro and P. J. Dyson (2005), Appl. Organomet. Chem. 19, 1. (b) A. Vessieres, S. Top, W. Beck, E. Hillard and G. Jaouen (2006), Dalton Trans. 529.

5. (a) W. H. Ang and P. J. Dyson (2006), Eur. J. Inorg. Chem. 4003. (b) M. Melchart and P. J. Sadler (2006), Bioorganometallics (Ed. Jaouen, G.), Wiley-VCH, Weinheim.

6. D. N. Akbayeva, L. Gonsalvi, W. Oberhauser, M. Peruzzini, F. Vizza, P. Brüggeller, A. Romerosa, G. Sava and A. Bergamo (2003), Chem. Commun. 264.

7. B. Serli, E. Zangrando, T. Gianferrara, C. Scolaro, P. J. Dyson, A. Bergamo and E. Alessio (2005), Eur. J. Inorg. Chem. 3423.

8. A. Dorcier, W. H. Ang, S. Bolaño, L. Gonsalvi, L. Juillerat-Jeanneret, G. Laurenczy, M. Peruzzini, A. D. Phillips, F. Zanobini, and P. J. Dyson (2006). Organometallics 25, 4090.

9. C. Scolaro, A. Bergamo, L. Brescacin, R. Delfino, M. Cocchietto, G. Laurenczy, T. J. Geldbach, G. Sava, and P. J. Dyson (2005). J. Med. Chem 48, 4161.

10. C. A. Vock, W. H. Ang, C. Scolaro, A. D. Phillips, L. Lagopoulos, L. Juillerat-Jeanneret, G. Sava, R. Scopelliti, and P. J. Dyson (2007). J. Med. Chem. 50, 2166.

11. (a) C. S Allardyce and P. J. Dyson (2001), J. Cluster Sci. 12, 563. (b) E. Rosenberg, F. Spada, K. Sugden, B. Martin, L. Milone, R. Gobetto, A. Viale and J. Fiedler (2003), J. Organomet. Chem. 668, 51.

12. D. Colangelo, A. Ghiglia, A. Ghezzi, M. Ravera, E. Rosenberg, F. Spada, and D. Osella (2005). J. Inorg. Biochem. 99, 505.

13. D. F. Baban and L. W. Seymour (1998). Adv. Drug Delivery Rev. 34, 109.

14. C. S. Allardyce, P. J. Dyson, D. J. Ellis, P. A. Salter, and R. Scopelliti (2003). J. Organomet. Chem. 668, 35.

15. M. Faure, M. Jahncke, A. Neels, H. Stoeckli-Evans, and G. Süss-Fink (1999). Polyhedron 18, 2679.

16. L. Vieille-Petit, G. Süss-Fink, B. Therrien, T. R. Ward, H. Stoeckli-Evans, G. Labat, L. Karmazin-Brelot, A. Neels, T. Bürgi, R. G. Finke, and C. M. Hagen (2005). Organometallics 24, 6104.

17. G. Meister, G. Rheinwald, H. Stoeckli-Evans and G. Süss-Fink (1994), J. Chem. Soc., Dalton Trans., 3215.

18. F. Chérioux, A. Maisse-François, A. Neels, H. Stoeckli-Evans and G. Süss-Fink (2001), J. Chem. Soc., Dalton Trans., 2184.

19. C. A. Vock, C. Scolaro, A. D. Phillips, R. Scopelliti, G. Sava, and P. J. Dyson (2006). J. Med. Chem. 49, 5552.

20. W. H. Ang, P. J. Dyson, B. Therrien and G. Süss-Fink, unpublished results. 
21. (a) L. Vieille-Petit, B. Therrien, G. Süss-Fink and T. R. Ward (2003), J. Organomet. Chem. 684, 117. (b) B. Therrien, L. Vieille-Petit and G. Süss-Fink (2004), Inorg. Chim. Acta. 357, 3284.

22. (a) B. Therrien, L. Vieille-Petit, G. Süss-Fink, Y. Sei and K. Yamaguchi (2004), J. Organomet. Chem. 689, 2820. (b) B. Therrien, L. Vieille-Petit and G. Süss-Fink (2005), J. Mol. Struct. 749, 183.

23. M. A. Bennett, A. K. Smith (1974), J. Chem. Soc., Dalton Trans. 233.

24. G. M. Sheldrick, SHELXS-97 (University of Göttingen, Göttingen, Germany, 1997).

25. G. M. Sheldrick, SHELXL-97 (University of Göttingen, Göttingen, Germany, 1997).

26. L. J. Farrugia (1997). J. Appl. Cryst. 30, 565. 